\title{
Effects of a single trace minerals injection on antioxidant and immune response, resistance to endoparasites, health and growth of newborn Boer kids ${ }^{1}$
}

\author{
Marcelo Vedovatto ${ }^{2}$, Ibrahim M. Cortada Neto², Dyego G. L. Borges ${ }^{3}$, \\ Rafaela N. Coelho ${ }^{3}$, Juliana Ranches ${ }^{4}$ and Gumercindo L. Franco ${ }^{3 *}$ (i)
}

\begin{abstract}
Vedovatto M., Cortada Neto I.M., Borges D.G.L., Coelho R.N., Ranches J. \& Franco G.L. 2021. Effects of a single trace minerals injection on an antioxidant and immune response, resistance to endoparasites, health and growth of newborn Boer kids. Pesquisa Veterinária Brasileira 41:e06722, 2021. Faculdade de Medicina Veterinária e Zootecnia, Universidade Federal de Mato Grosso do Sul, Av. Senador Felinto Muller 2443, Campo Grande, MS 79070-900, Brazil. E-mail: gumercindo.franco@ufms.br

This study evaluated the effects of injectable trace minerals (ITM) on antioxidant and immune response, resistance to endoparasites, health and growth of newborn Boer kids. Forty-six Boer kids [24 males and 22 females; 3.94 $\pm 1.03 \mathrm{~kg}$ of body weight (BW); $6.2 \pm 2.4 \mathrm{~d}$ of age] were enrolled in the study. Kids were stratified by type of birth (twins or singlet), sex, and BW and assigned to 1 of 2 treatments: one subcutaneous injection $(0.1 \mathrm{~mL} / 4.5 \mathrm{~kg}$ of BW) of (1) saline solution or (2) ITM $(60,10,5$, and $15 \mathrm{mg} / \mathrm{mL}$ of $\mathrm{Zn}, \mathrm{Mn}$, Se and $\mathrm{Cu}$, respectively). Blood samples were collected on d 0, 7, 14, 28 and 56. Feces samples were collected on d 56 and BW on d 0, 28 and 56. Kids were checked daily for signs of diarrhea. ITM kids had greater $(P<0.01)$ plasma concentration of superoxide dismutase and tended $(P=0.06)$ to have greater plasma concentration of glutathione peroxidase. ITM kids had greater $(P=0.05)$ concentration of eosinophils, but no differences $(P \geq 0.11)$ were observed for other hemogram variables. The ITM application did not affect $(P \geq 0.11)$ the EPG count. However, ITM kids had less $(P=0.02)$ cumulative incidence of diarhea until d 42 (3.85 vs. $25.93 \pm 6.8 \%$ for ITM vs. Saline kids, respectively) but no differences $(P>0.10)$ were observed after $\mathrm{d} 42$. The ITM application did not affect $(P \geq 0.40)$ the growth of kids $(0.071$ vs. $0.065 \pm 0.005 \mathrm{~kg} /$ day for ITM vs. Saline kids, respectively). Thus, the ITM application, increased the plasma concentration of antioxidant enzymes and eosinophils, decreased the incidence of diarrhea only in the middle of the experiment, but did not affected the EPG count and growth of Boer kids.
\end{abstract}

INDEX TERMS: Mineral injection, antioxidant, immune response, resistance, endoparasites, newborn Boer kids, diarrhea, Eimeria, glutathione peroxidase, hemogram, superoxide dismutase.

RESUMO.- [Efeitos de uma aplicação de microminerais injetáveis sobre a resposta antioxidante e imunológica, resistência a endoparasitas, saúde e crescimento de cabritos Boer recém-nascidos.] Este estudo avaliou os efeitos de microminerais injetáveis (ITM) na resposta antioxidante

\footnotetext{
${ }^{1}$ Received on December 14, 2020.

Accepted for pulication on December 28, 2020.

${ }^{2}$ Universidade Estadual de Mato Grosso do Sul (UFMS), Campus de Aquidauana, Rua Oscar Trindade de Barros 740, Da Serraria Aquidauana, MS 79200-000, Brazil.

${ }^{3}$ Faculdade de Medicina Veterinária e Zootecnia (FAMEZ), Universidade Federal de Mato Grosso do Sul (UFMS), Av. Senador Felinto Muller 2443, Campo Grande, MS 79070-900, Brazil. *Corresponding author: gumercindo.franco@ufms.br

${ }^{4}$ Eastern Oregon Agricultural Research Center, Oregon State University, Burns, OR 97720, USA.
}

e imune, resistência a endoparasitas, saúde e crescimento de cabritos Boer recém-nascidos. Quarenta e seis cabritos [24 fêmeas e 22 machos; $3,94 \pm 1,03 \mathrm{~kg}$ de peso corporal (PC); $6,2 \pm 2,4$ dias de idade] foram incluídos no estudo. Os animais foram estratificados por tipo de nascimento (gêmeos ou singular), sexo e peso ao nascimento (PN) e atribuídas a 1 de 2 tratamentos. Uma injeção subcutânea $(0,1 \mathrm{ml} / 4,5$ de PC de (1) Solução salina ou (2) ITM $(60,10,5$ e $15 \mathrm{mg} / \mathrm{ml}$ de Zn, $\mathrm{Mn}$, Se e $\mathrm{Cu}$, respectivamente). As amostras de sangue foram coletadas nos dias $0,7,14,28$ e 56 . As amostras de fezes foram coletadas no dia 56 e PC nos dias 0,28 e 56 . Os recém-nascidos foram verificados diariamente quanto a sinais de diarreia. Os cabritos ITM apresentaram maior $(P<0.01)$ concentração de superóxido desmutase no plasma e tenderam $(\mathrm{P}=0,06)$ a ter 
maior concentração de glutationa peroxidase no plasma. Os animais ITM apresentaram maior $(P=0,05)$ concentração de eosinófilos, mas não foram observadas diferenças $(P \geq 0.11)$ para outras variáveis do hemograma. A aplicação de ITM não afetou ( $P \geq 0.11)$ a contagem de EPG. No entanto, os cabritos ITM apresentaram menor incidência cumulativa de diarreia $(P=0,02)$ ate $\mathrm{d} 42(3,85$ vs. $25,93 \pm 6,8 \%$ para animais ITM vs. animais salina, respectivamente), mas nenhuma diferença $(P>0.10)$ foi observada após d 42. A aplicação do ITM não afetou $(P \geq 0.40)$ o crescimento dos animais ( 0.071 vs. $0.065 \pm 0.005 \mathrm{~kg} /$ dia para ITM vs. Salina, respectivamente). Assim, a aplicação do ITM aumentou a concentração plasmática de enzimas antioxidantes e eosinófilos, diminuiu a incidência de diarreia somente na metade do experimento, mas não afetou a contagem de $\mathrm{OPG}$ e crescimento de cabritos Boer recém-nascidos.

TERMOS DE INDEXAÇÃO: Microminerais injetáveis, antioxidante, imunologia, resistência, endoparasitas, cabritos Boer, recém-nascidos, diarreia, Eimeria, glutationa peroxidase, hemograma, superóxido desmutase.

\section{INTRODUCTION}

Trace minerals injection (ITM) is an alternative method to the conventional mineral supplementation strategies. Among benefits within the use of ITM is that it provides a known amount of trace minerals for all animals of the same group and avoids the interference of antagonists that might be present in the diet (Arthington et al. 2014). Additionally, ITM is an interesting method for trace minerals supplementation to new-borns mammals that have low solid feed intake, and consequently low minerals intake, if they are provided by the conventional forms.

It has been reported that the application of ITM containing $\mathrm{Zn}, \mathrm{Mn}, \mathrm{Se}$ and $\mathrm{Cu}$ in beef cows (Vedovatto et al. 2019a, 2019b), weaned calves (Vedovatto et al. 2019c) and lambs (Cazarotto et al. 2018, 2019) increased the concentration of superoxide dismutase (SOD) and glutathione peroxidase (GSH-Px). Increased concentration of antioxidants enzymes by ITM, results in improved immune system (Cazarotto et al. 2018, Vedovatto et al. 2019c) and less incidence of diseases (Teixeira et al. 2014). Further, the application of ITM in calves reduced the incidence of diarrhea (Teixeira et al. 2014, Glombowsky et al. 2018, Tomasi et al. 2018). For this reason, we hypothesized that the application of ITM in newborn kids could reduce the incidence of diarrhea from birth to weaning.

Although, many studies have evaluated the use of ITM in ruminants, the majority of the research has been done in cattle (Arthington et al. 2014, Teixeira et al. 2014, Glombowsky et al. 2018, Vedovatto et al. 2019a, 2019b, 2019c) and lambs (Cazarotto et al. 2018, 2019). To the knowledge of the authors, no studies looking into ITM injection for goats have been published in the literature.

The use of ITM in goats is interesting method for trace minerals supplementation of rangeland-managed goats, as commonly seen in tropical regions. The use of ITM in this settings alleviates the difficulties associated to the conventional mineral supplementation, such as free-choice supplementation, resulting in adequate delivery of trace minerals for each individual. Therefore, we hypothesized that the application of ITM in newborn kids will improve the immune system and resistance to endoparasites, reduce the incidence of diarrhea and enhance growth of kids when compared to saline-injected kids. Thus, the objective of this study was to evaluate the effects of ITM on antioxidant and immune response, resistance to endoparasites, health and growth of newborn Boer kids.

\section{MATERIALS AND METHODS}

Ethics statement. The study was conducted according to the ethical standards applied to animal research and approved by the ethics committee on animal use of the "Universidade Federal de Mato Grosso do Sul" (UFMS) under the protocol no. 754/2016.

Animals, treatments and samples collection. The study was conducted in a commercial farm located in Bandeirantes/MS, Brazil (1953'15.9" latitude south and 54 ${ }^{\circ} 24^{\prime} 43.0^{\prime \prime}$ longitude west) during the Spring season (temperature-humidity index ranged from 73.6 to 77.6) and lasted 56 days. The goats (mothers) remained during the first four months of gestation on pasture of marandu-grass [Urochloa brizantha (Hochst. ex A. Rich) R. D. Webster, cv. Marandu]. Further, on the last month of gestation, were transferred to a feedlot, were they received corn silage and concentrate to meet or exceed the requirements for crude protein and minerals for goats weighing $50 \mathrm{~kg}$ (double-kids) at late gestation and early lactation (NRC 2007). After the delivery, the kids remained with the mothers until at least 3 days post-partum to allow colostrum consumption. Subsequentially, the kids were transferred on the same day to a single experimental pen, where they were kept as a single group until the end of the study. Forty-six Boer kids (24 males and 22 females; $3.94 \pm 1.03 \mathrm{~kg}$ of BW; $6.2 \pm 2.4 \mathrm{~d}$ of age) were enrolled in the study. Kids were stratified by type of birth (twins or singlet), sex and body weight (BW), and then randomly assigned into 1 of 2 treatments: one single subcutaneous injection $(0.1 \mathrm{~mL} / 4.5 \mathrm{~kg}$ of BW) of saline solution (Saline) or ITM. Saline solution consisted of $0.9 \% \mathrm{NaCl}$, whereas ITM composition was $60,10,5$, and $15 \mathrm{mg} / \mathrm{mL}$ of $\mathrm{Zn}, \mathrm{Mn}$, Se and Cu, respectively (Multimin 90, Multimin, Fort Collins/CO, USA). Injections were administered on the right side of the neck of each kid.

The experimental pen $\left(60 \mathrm{~m}^{2}\right)$ was located in a covered shed with open laterals, providing good natural ventilation. The pen was equipped with one automatic drink fountain and two feed bunks with $10 \mathrm{~cm}$ linear/animal. One feed bunk was used to provide fresh chopped forage [Megathyrsus maximus (Jacq.) B.K. Simon \& S.W.L. Jacobs; cv. Colonião] and the other feed bunk was used to provide concentrate (Table 1). The feed was offered two times daily $(0800 \mathrm{~h}$ and $1600 \mathrm{~h}$ ) ad libitum. Milk replacer (Sprayfo Lamb Primo ${ }^{\circledR}$, Trouw Nutrition, Mirassol/SP, Brazil) was diluted in water (1:6 respectively) at $37^{\circ} \mathrm{C}$ and provided $250 \mathrm{~mL} / \mathrm{kid}$, twice daily $(0800 \mathrm{~h}$ and $1600 \mathrm{~h})$, using an individual graduated bottle.

On day 0 , all kids were weighed (before the ITM or Saline injection) with following body weight collections on days 28 and 56. The kids were vaccinated against clostridiosis (Sintoxan ${ }^{\circledR}$ 9TH, Merial Saúde Animal, Brazil), pasteurellosis and paratyphoid (Tifopasteurina ${ }^{\circledR}$, Hertape Calier Saúde Animal, Brazil) at 30 days of age. No deworming practice was conducted during the study. Additionally, the occurrence of diarrhea was observed daily by the same trained veterinarian, following the methodology described by Larson et al. (1977), which is based on fecal score of fluidity: (1) normal; (2) soft; (3) runny and (4) watery. Diarrhea was confirmed if the animals presented scores 3 or 4 for 2 or more consecutive days. For this, the veterinarian remained in the farm throughout the study, and evaluate the kids individually, many times during the day, to detected the fluidity of the feces, that was noted in spreadsheets. 
Blood samples were collected from jugular vein on $\mathrm{d} 0,7,14,28$ and 56 into blood collection tubes (BD Vacutainer ${ }^{\circledR}$, Becton Dickinson, Franklin Lakes/NJ, USA) containing sodium heparin (5mL) or $\mathrm{K}_{2}$ EDTA $(4 \mathrm{~mL})$. After collection, blood samples were immediately stored on ice. Blood samples containing sodium heparin were centrifuged at $1200 \times \mathrm{g}$ for $30 \mathrm{~min}$ for plasma harvest. Plasma samples were stored at $-20^{\circ} \mathrm{C}$ for further analysis of the concentration of SOD and GSHPx. Blood samples containing $\mathrm{K}_{2}$ EDTA were stored at $4^{\circ} \mathrm{C}$ overnight, and haematological analyses performed in these samples until 24 hours after collection.

Fecal samples were collected on day 56, directly from the rectal ampulla, immediately stored on ice, and analysed within 24 hours after collection. Chopped forage samples were collected, dried at $60^{\circ} \mathrm{C}$ for 5 days, ground to $1 \mathrm{~mm}$ and analysed for chemical composition.

Laboratory analysis. Forage was analysed according to AOAC (2000): crude protein, method 976.05; ether extract, method 920.39 and ash, method 942.05. The concentration of neutral detergent fiber was done according to the methodology of Van Soest et al. (1991). The trace minerals concentration of forages was analysed via inductively coupled plasma mass spectrometry, and Se was analysed as described by Oliveira et al. (2016) and the other minerals as described by Braselton et al. (1997). The trace minerals status of the kids was not accessed in this study as a liver biopsy procedure (best indicator for trace minerals status) would be too invasive for newborn kids. Further, the TM analysis in blood is not the most reliable indicator of trace minerals status (Herdt et al. 2000, Ranches et al. 2018). Thus, the lack of knowledge of the TM status of the kids is limitation of this study.

Table 1. Chemical composition of forage ([Megathyrsus maximus (Jacq.) B.K. Simon \& S.W.L. Jacobs Panicum maximum; cv. Colonião)], concentrate and milk replacer provided to kids during the study

\begin{tabular}{lccc}
\hline \multicolumn{1}{c}{ Items } & Forage $^{\mathrm{a}}$ & Concentrate $^{\mathrm{b}, \mathrm{c}}$ & Milk replacer $^{\mathrm{b}, \mathrm{d}}$ \\
\hline g/kg of dry matter (DM) & & & \\
Crude protein & 71.51 & 215.00 & 220.00 \\
Neutral detergent fiber & 781.46 & 214.00 & 1.00 \\
Ether extract & 23.74 & 30.00 & 220.00 \\
Ash & 76.05 & 96 & 89.00 \\
Calcium & 1.85 & 10.00 & 9.00 \\
Phosphorus & 1.77 & 4.00 & 6.00 \\
Sodium & 2.59 & 1.50 & 7.00 \\
Potassium & 17.09 & 5.50 & - \\
Magnesium & 0.98 & 2.00 & - \\
mg/kg of DM & & & \\
Iron & 144.48 & 85.00 & 30.00 \\
Zinc & 25.95 & 35.00 & 84.00 \\
Manganese & 32.47 & 35.00 & 45.00 \\
Selenium & 0.06 & 1.20 & 0.3 \\
Copper & 5.09 & 25.00 & 10 \\
\hline
\end{tabular}

a Chemical composition analyzed; ${ }^{\mathrm{b}}$ guarantee levels described by the manufacturers; ' Caprinos Creep Caprivales, "Só Sal Nutrição e Saúde Animal", Campo Grande/MS, Brazil; d Sprayfo Lamb Primo ${ }^{\circledR}$, Trouw Nutrition, Mirassol/SP, Brazil; Diluted in water $\left(1: 6\right.$ respectively) at $37^{\circ} \mathrm{C}$.
The enzymes GSH-Px and SOD were determined by commercial kits (Cayman Chemical, Ann Arbor/MI, USA, catalogue number 703102 and 706002, respectively). The inter and intra-assay coefficients of variation for SOD were 4.5 and $7.2 \%$ and for GSH-Px were 6.1 and $8.1 \%$, respectively.

The hemogram analysis was performed in whole blood samples in automated equipment (pocH-100iV DIFF Sysmex) as described by Riond et al. (2011). The parasite load determined by the EPG was performed as described by Gordon \& Whitlock (1939).

Statistics. Kid was considered the experimental unit for all analyses. All dependent variables were tested for normality using Univariate procedure of SAS (SAS Inst. Inc., Cary/NC, USA; version 9.4). The variable EPG did not have normal distribution and were transformed to $\log _{10}(X+1)$. Plasma concentrations of SOD and GSH-Px, blood concentration of immune cells, BW, average daily gain (ADG) and EPG (transformed) were analysed using MIXED procedure of SAS. Satterthwaite approximation was used to determine the denominator degrees of freedom for the test of fixed effects. Kid ADG and EPG were tested for fixed effect of treatment using sex and kid (treatment) as random effects. Kid BW, plasma concentrations of SOD and GSH-Px, and blood concentrations of immune cells were analysed as repeated measures and tested for fixed effects of treatment, day, and treatment $\times$ day, using sex and kid (treatment) as random variables and kid(treatment) as subject. All results obtained on day 0 for each variable were included as covariates in each respective analysis but were removed from the model when $P>0.10$. The first order autoregressive covariance structure was selected for BW, eosinophils, mean corpuscular volume, mean corpuscular haemoglobin, mean corpuscular haemoglobin concentration and platelets. The compound symmetric covariance structure was selected for SOD, leukocytes, lymphocytes, monocytes, haemoglobin and haematocrit. The Toepliz covariance structure was selected for neutrophils, erythrocytes and GSH-Px. The covariance structures were selected according to the lowest Akaike information criterion. The binary data of cumulative diarrhea incidence was analysed using the GLIMMIX procedure of SAS with Satterthwaite approximation to determine the denominator degrees of freedom for tests of fixed effects. The diarrhea incidence was tested for fixed effect of treatment using sex and kid (treatment) as random effect. Means were separated using PDIFF and all results were reported as LSMEANS followed by SEM. The SAS commands used in this study are presented in the supplementary material. Significance was defined when $P \leq 0.05$, and tendency when $P>0.05$ and $\leq 0.10$.

\section{RESULTS}

Effects of treatment $\times$ day, and treatment were detected $(P<0.01)$ for plasma concentrations of SOD (Table 2). Kids assigned to ITM treatment had greater concentrations of SOD on $\mathrm{d} 7,14,28$ and 56 , when compared to kids assigned to Saline treatment (Fig.1). A tendency for a treatment effect $(P=0.06)$ but no effect of treatment $\times$ day $(P=0.24)$ was observed for plasma GSH-Px. Kids assigned to ITM treatment tended to have greater concentrations of plasma GSH-Px when compared to kids assigned to Saline treatment (Table 2).

Effect of treatment $(P=0.05)$, but not treatment $\times$ day $(P=0.56)$ was observed for eosinophils. Kids assigned to ITM treatment had greater eosinophils concentrations when compared to kid assigned to the Saline treatment (Table 2). No effects of treatment $x$ day or treatment were detected $(P \geq 0.11)$ for the others hemogram variables (Table 2$)$. 
No effect of treatment was detected $(P \geq 0.11)$ for eggs/ oocists count of Strongyle, Strongyloides, Trichuris, Eimeria or total eggs/oocists count per gram of feces (Table 3). A tendency for treatment effect $(P=0.06)$ was observed for the cumulative incidence of diarrhea on day 28. Further, a treatment effect $(P=0.02)$ was observed on day 35 and 42 , where kids assigned to ITM treatment had lower incidence on these days, when compared to kids assigned to Saline treatment (Fig.2). No kid mortality was observed during the study.

No effect of treatment $x$ day or treatment was detected for BW $(P \geq 0.55)$. Similarly, no effect $(P \geq 0.40)$ of treatment was detected for ADG during the study (Table 4).

\section{DISCUSSION}

The ITM application increased the plasma concentration of SOD and GSH-Px in kids. Similar response was previously observed in cows (Vedovatto et al. 2019a, 2019b), calves (Glombowsky et al. 2018, Vedovatto et al. 2019c) and lambs (Cazarotto et al. 2018, 2019). This response is likely due to the structural formation of the superoxide dismutase, where $\mathrm{Zn}, \mathrm{Mn}$ and $\mathrm{Cu}$ are constituent of the enzymes $\mathrm{Cu} / \mathrm{Zn}-\mathrm{SOD}$ and Mn-SOD. Further, Se is constituent of the GSH-Px (Sordillo \& Aitken 2009) and increased enzymatic concentration observed in the current study should be expected with the increased systemic mineral concentration. Improving enzymatic concentration of SOD and GSH-Px is important, because these antioxidants enzymes can reduce the concentration of reactive species oxygen and consequently reduce damage caused by the oxidative stress in the cells (Cazarotto et al. 2019).

The ITM application increased the concentration of eosinophils in kids. A similar response was previously reported in calves (Vedovatto et al. 2019c) but not in lambs (Cazarotto et al. 2018). In the current study, the increased concentration of eosinophil observed in kids receiving ITM injection can be attributed to Se mitogenic properties, inducing the proliferation of eosinophils by changes on mitotic index (Hawkes et al. 2001). Another explanation may be related to a better control of the damage caused by oxidative stress

Table 2. Blood concentrations of antioxidants enzymes, leukogram, erytogram and platelets in Boer kids administered a single subcutaneous injection $(0.1 \mathrm{~mL} / 4.5 \mathrm{~kg}$ of body weight) of saline solution or injectable trace mineral (ITM)

\begin{tabular}{|c|c|c|c|c|c|}
\hline \multirow{2}{*}{ Items $^{\mathrm{a}}$} & \multicolumn{2}{|c|}{ Treatments $^{\mathrm{b}}$} & \multirow{2}{*}{ SEM } & \multicolumn{2}{|c|}{$P$-value } \\
\hline & Saline & ITM & & Treatment $\times$ day & Treatment \\
\hline \multicolumn{6}{|l|}{ Antioxidants enzymes } \\
\hline Superoxide dismutase, $\mathrm{U} / \mathrm{mL}$ & 1.84 & 3.01 & 0.12 & $<0.01$ & $<0.01$ \\
\hline \multicolumn{6}{|l|}{ Leukogram } \\
\hline Leukocytes, $\times 10^{3}$ cells $/ \mu \mathrm{L}$ & 15.15 & 16.39 & 0.77 & 0.79 & 0.29 \\
\hline Monocytes, $\times 10^{3}$ cells $/ \mu \mathrm{L}$ & 0.30 & 0.22 & 0.14 & 0.62 & 0.69 \\
\hline Eosinophils, $\times 10^{3}$ cells $/ \mu \mathrm{L}$ & 0.09 & 0.29 & 0.06 & 0.56 & 0.05 \\
\hline \multicolumn{6}{|l|}{ Erytogram } \\
\hline Erythrocytes, $\times 10^{6}$ cells $/ \mu \mathrm{L}$ & 14.62 & 15.40 & 0.35 & 0.95 & 0.15 \\
\hline Haemoglobin, g/dL & 10.06 & 10.40 & 0.24 & 0.66 & 0.34 \\
\hline Platelets, $\times 10^{3}$ cells $/ \mu \mathrm{L}$ & 129.06 & 123.76 & 8.15 & 0.11 & 0.65 \\
\hline
\end{tabular}

Table 3. Eggs per gram of feces in Boer kids administered a single subcutaneous injection $(0.1 \mathrm{~mL} / 4.5 \mathrm{~kg}$ of body weight) of saline solution or injectable trace mineral (ITM)

\begin{tabular}{lcccr}
\hline \multirow{2}{*}{ Items } & \multicolumn{2}{c}{ Treatments $^{1}$} & \multirow{2}{*}{ SEM } & P-value \\
\cline { 2 - 3 } $\log _{10}$ of eggs/g of faeces & Saline & ITM & & \\
$\quad$ Strongyle & $1.78(268.33)$ & $1.49(151.79)$ & 0.30 & 0.47 \\
Strongyloides & $0.36(2.33)$ & $0.22(1.43)$ & 0.10 & 0.33 \\
Trichuris & $0.69(4.66)$ & $0.52(3.57)$ & 0.09 & 0.10 \\
Eimeria & $1.14(13.01)$ & $0.85(6.43)$ & 0.11 \\
Total & $2.10(288.33)$ & $1.85(163.21)$ & 0.21 & 0.28
\end{tabular}

${ }^{a}$ Saline solution consisted of $0.9 \% \mathrm{NaCl}$, whereas ITM had $60,10,5$, and $15 \mathrm{mg} / \mathrm{mL}$ of Zn, Mn, Se and Cu, respectively (Multimin ${ }^{\circledR} 90$, Multimin, Fort Collins/ CO, USA); Both treatments were administered on the right side of the neck of each kid; Values in parentheses represent the original number of eggs per gram without being transformed to $\log _{10}$. 
to these leukocytes due to the greater production of SOD and GSH-Px. Immune cells are sensitive to oxidative stress because they have membranes with high concentrations of polyunsaturated fatty acids, which are highly susceptible to lipid peroxidation (Spears \& Weiss 2008).

Kids assigned to ITM treatment did not have greater resistance do endoparasites, when compared to kids assigned to the Saline treatment. ITM injection in newborn lambs reduced the faecal number of Eimeria spp. oocysts, and the authors attribute the improvement in immune system caused by the ITM application (Cazarotto et al. 2018). In our study,

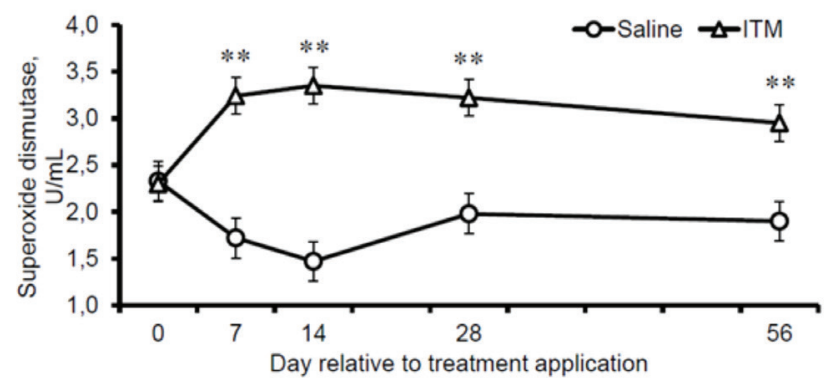

Fig.1. Plasma concentration of superoxide dismutase in Boer kids administered a single subcutaneous injection $(0.1 \mathrm{~mL} / 4.5 \mathrm{~kg}$ of body weight) of saline solution or injectable trace mineral (ITM). Effects of treatment $\times$ day were detected $(P \leq 0.01) . P \leq 0.05\left(^{* *}\right)$.

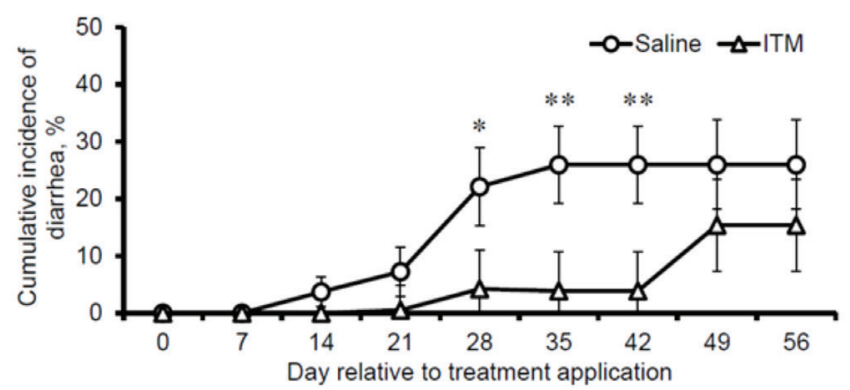

Fig.2. Cumulative incidence of diarrhea in Boer kids administered a single subcutaneous injection $(0.1 \mathrm{~mL} / 4.5 \mathrm{~kg}$ of body weight) of saline solution or injectable trace mineral (ITM). A tendency $(P=0.06)$ for treatment effect was observed on day 28 and treatment effects $(P=0.02)$ were observed d 35 and $42 . P \leq 0.10$ $\left.{ }^{*}\right)$ and $P \leq 0.05\left(^{* *}\right)$. we only apply the ITM on day 0 , differing from the study of Cazarotto et al. (2018), that was applied on day 0 and again on day 30; it could explain the differences between studies. The absence of the evaluation of TM status in our study, did not allow to evaluate the interval that ITM should be applied, and further studies exploring this effect deserve be investigate. In other study, the administration of oral copper capsules reduced the EPG count of Haemonchus contortus in sheep feces, but the authors attribute this result to a direct effect of $\mathrm{Cu}$ on the parasite, suggested that dietary $\mathrm{Cu}$ damages the parasite cuticle, resulting in its inability to maintain infection; rather than an indirect effect of improved immune system (Campigotto et al. 2019).Thus, in the current study, the improved concentration of eosinophils, did not reflected in better resistance to endoparasites in ITM kids.

In the current study, kids assigned to the ITM treatment had lower incidence of diarrhea, compared to kid assigned to Saline. Similarly, the application of ITM in calves on day 0 and 30 days of age, reduced the incidence of diarrhea (41.7 and 49.7\% for ITM and saline respectively) and pneumonia, otitis or both (41.6 and 49.1\% for ITM and Saline respectively) (Teixeira et al. 2014). In other studies, the ITM application at birth (Tomasi et al. 2018) or on day 2 and again on day 14 (Glombowsky et al. 2018) reduced the severity of the diarrhea, occurrence of pneumonia and the use of antibiotics in dairy calves. In the current study, ITM injection increased plasma concentrations of antioxidant enzymes which may have reduced the damage caused by the oxidative stress to the immune cells leading to a reduction in the incidence of diarrhea, by reducing the pathogenic bacteria infection in the gastrointestinal tract. To support this rationale, it has been previously demonstrated that the total count of bacteria in faeces, was lower in calves that received an ITM application (Glombowsky et al. 2018). Further, Zn supplementation exhibits therapeutic action by facilitating the transport of water and electrolytes across the intestinal mucosa, preventing villous atrophy and improving overall immunity, consequently, reducing the incidence of acute diarrhea (Tomkins et al. 1993).

The use of ITM improved the immune and antioxidant systems and the health of the kids. However, these outcomes did not lead to enhanced growth performance when compared to Saline injection. Similar responses were observed in previous studies using ITM, where ITM application also did not improve the growth of calves (Arthington et al. 2014, Teixeira et al. 2014, Glombowsky et al. 2018, Vedovatto et al. 2019c) as observe d in the current study with kids.

Table 4. Growth performance of Boer kids administered a single subcutaneous injection $(0.1 \mathrm{~mL} / 4.5 \mathrm{~kg}$ of body weight) of saline solution or injectable trace mineral (ITM)

\begin{tabular}{|c|c|c|c|c|c|}
\hline \multirow{2}{*}{ Items } & \multicolumn{2}{|c|}{ Treatments $^{\mathrm{a}}$} & \multirow{2}{*}{ SEM } & \multicolumn{2}{|c|}{$P$-value } \\
\hline & Saline & ITM & & Treatment $\times$ day & Treatment \\
\hline Body weight, kg & & & & 0.55 & 0.65 \\
\hline d 0 & 3.97 & 3.90 & 0.20 & & \\
\hline $\mathrm{d} 28$ & 5.41 & 5.50 & 0.20 & & \\
\hline d 56 & 7.61 & 7.89 & 0.20 & & \\
\hline \multicolumn{6}{|c|}{ Average daily gain, kg/d } \\
\hline d 0 to 28 & 0.051 & 0.057 & 0.005 & & 0.45 \\
\hline d 28 to 56 & 0.078 & 0.085 & 0.007 & & 0.53 \\
\hline d 0 to 56 & 0.065 & 0.071 & 0.005 & & 0.40 \\
\hline
\end{tabular}

a Saline solution consisted of $0.9 \% \mathrm{NaCl}$, whereas ITM had 60, 10, 5, and 15mg/mL of Zn, Mn, Se and Cu, respectively (Multimin 90, Multimin, Fort

Collins/CO, USA); Both treatments were administered on the right side of the neck of each kid. 


\section{CONCLUSIONS}

To the knowledge of the authors, this is the first publication evaluating the effects of injectable trace minerals (ITM) in goats.

The application of ITM increased the levels of eosinophils, SOD and GSH-Px, decreased the incidence of diarrhea only in the midle of the experiment, but did not affected the EPG count and the growth of Boer kids.

Acknowledgements.- The authors acknowledge the "Coordenação de Aperfeiçoamento de Pessoal de Nível Superior" (CAPES) by the scholarship provided to the first author, the "Fundação de Apoio ao Desenvolvimento do Ensino, Ciência e Tecnologia do Estado de Mato Grosso do Sul" (FUNDECT, 116/2016) for sponsoring the study, the company Multimin (Fort Collins/CO, USA) for the donation of the ITM and to the company Apris Cabrito for allowing to perform the experiment at Água Boa Farm (Bandeirantes/MS, Brazil).

Conflict of interest statement.- The authors have no competing interests.

\section{REFERENCES}

AOAC 2000. Official Methods of Analysis. 17th ed. Association of Official Analytical Chemists, Gaithersburg, MD, USA.

Arthington J.D., Moriel P., Martins P.G.M.A., Lamb G.C. \& Havenga L.J. 2014. Effects of trace mineral injections on measures of performance and trace mineral status of pre- and postweaned beef calves. J. Anim. Sci., 92(6):26302640. <https://dx.doi.org/10.2527/jas.2013-7164><PMid:24867937>

Braselton W.E., Stuart K.J., Mullaney T.P. \& Herdt T.H. 1997. Biopsy mineral analysis by inductively coupled plasma-atomic emission spectroscopy with ultrasonic nebulization. J. Vet. Diagn. Invest. 9(4):395-400. <https://dx.doi. org/10.1177/104063879700900409><PMid:9376429>

Campigotto G., Gebert R.R., Santos D.S., Dos Reis J.H., Alba D.F., Cazarotto C.J., Leal M.L.R., Baldissera M.D., Lopes T.F., Druzian L.T., Morsch V.M., Vedovatto M. \& Da Silva A.S. 2019. Effects of oral administration of copper capsules on helminth control in lactating dairy sheep: an effective alternative to replace conventional antiparasitics during lactation. Exp. Parasitol. 205:107735. <https://dx.doi.org/10.1016/j.exppara.2019.107735><PMid:31381870>

Cazarotto C.J., Boito J.P., Gebert R.R., Reis J.H., Machado G., Bottari N.B., Morsch V.M., Schetinger M.R.C., Doleski P.H., Leal M.L.R., Baldissera M.D. \& Da Silva A.S. 2018. Metaphylactic effect of minerals on immunological and antioxidant responses, weight gain and minimization of coccidiosis of newborn lambs. Res. Vet. Sci. 121:46-52. <https://dx.doi.org/10.1016/j. rvsc.2018.09.003><PMid:30317064>

Cazarotto C.J., Boito J.P., Glombowsky P., Baggio R.A., Galli G.M., Machado G., Bottari N.B., Leal M.L.R., Kessler J.D., Baldissera M.D. \& Da Silva A.S. 2019. Nutraceutical effect of trace elements as additional injectable doses to modulate oxidant and antioxidant status, and improves the quality of lamb meat. Biol. Trace Elem. Res. 191(1):115-125. <https://dx.doi.org/10.1007/ s12011-018-1612-7><PMid:30600498>

Glombowsky P., Da Silva A.S., Soldá N.M., Galli G.M., Biazus A.H., Campigotto G., Bottari N.B., Sousa R.S., Brisola M.C., Stefani L.M., Baldissera M.D., Leal M.L.R., Morsch V.M., Schetinger M.R.C. \& Machado G. 2018. Mineralization in newborn calves contributes to health, improve the antioxidant system and reduces bacterial infections. Microb. Pathog. 114:344-349. <https://dx.doi.org/10.1016/j.micpath.2017.12.012><PMid:29223451>

Gordon H. \& Whitlock H.V. 1939. A new technique for counting nematode eggs in sheep faeces. J. CSIR 12(1):50-52.

Hawkes W.C., Kelley D.S. \& Taylor P.C. 2001. The effects of dietary selenium on the immune system in healthy men. Biol. Trace Elem. Res. 81(3):189213. <https://dx.doi.org/10.1385/BTER:81:3:189> <PMid:11575678>

Herdt T.H., Rumbeiha W. \& Braselton W.E. 2000. The use of blood analyses to evaluate mineral status in livestock. Vet. Clin. N. Am., Food Anim. Pract. 16(3):423-444.<https://dx.doi.org/10.1016/S0749-0720(15)30078-5> $<$ PMid:11084984>
Larson L.L., Owen F.G., Albright J.L., Appleman R.D., Lamb R.C. \& Muller L.D. 1977. Guidelines toward more uniformity in measuring and reporting calf experimental data. J. Dairy Sci. 60(6):989-991. <https://dx.doi.org/10.3168/ jds.S0022-0302(77)83975-1>

NRC 2007. Nutrient Requirements of Small Ruminant: sheep, goats, cervides and new world camelids. National Academy Press, Washington, DC.

Oliveira A.F., Landero J., Kubachka K., Nogueira A.R.A., Zanetti M.A. \& Caruso J. 2016. Development and application of a selenium speciation method in cattle feed and beef samples using HPLC-ICP-MS: evaluating the selenium metabolic process in cattle. J. Anal. At. Spectrom. 31(4):1034-1040.<https:// dx.doi.org/10.1039/C5JA00330J>

Ranches J., Pardelli U., Cordero J., Piccolo M.B., Silva G. \& Arthington J. 2018. Comparison of liver and blood as indicators of Se and $\mathrm{Cu}$ status in beef cows. J. Anim. Sci., Champaign, 96(Supl.3):381.

Riond B., Weissenbacher S., Hofmann-Lehmann R. \& Lutz H. 2011. Performance evaluation of the Sysmex pocH-100iV Diff hematology analyzer for analysis of canine, feline, equine, and bovine blood. Vet. Clin. Pathol. 40(4):484-495. <https://dx.doi.org/10.1111/j.1939-165X.2011.00372.x><PMid:22092369>

Sordillo L.M. \& Aitken S.L. 2009. Impact of oxidative stress on the health and immune function of dairy cattle. Vet. Immunol. Immunopathol. 128(1/3):104-109.<https://dx.doi.org/10.1016/j.vetimm.2008.10.305> <PMid:19027173>

Spears J.W. \& Weiss W.P. 2008. Role of antioxidants and trace elements in health and immunity of transition dairy cows. Vet. J. 176(1):70-76. <https://dx.doi.org/10.1016/j.tvjl.2007.12.015> <PMid:18325801>

Teixeira A.G.V., Lima F.S., Bicalho M.L.S., Kussler A., Lima S.F., Felippe M.J. \& Bicalho R.C. 2014. Effect of an injectable trace mineral supplement containing selenium, copper, zinc, and manganese on immunity, health, and growth of dairy calves. J. Dairy Sci. 97(7):4216-4226. <https://dx.doi. org/10.3168/jds.2013-7625><PMid:24835970>

Tomkins A., Behrens R. \& Roy S. 1993. The role of zinc and vitamin A deficiency in diarrhoeal syndromes in developing countries. Proc. Nutr. Soc. 52(1):131142. <https://dx.doi.org/10.1079/PNS19930045><PMid:8493258>

Tomasi T., Volpato A., Pereira W.A.B., Debastiani L.H., Bottari N.B., Morsch V.M., Schetinger M.R.C., Leal M.L.R., Machado G. \& Da Silva A.S. 2018. Metaphylactic effect of minerals on the immune response, biochemical variables and antioxidant status of newborn calves. J. Anim. Physiol. Anim. Nutr. 102(4):819-824. <https://dx.doi.org/10.1111/jpn.12890> <PMid:29603406>

Van Soest P.J., Robertson J.B. \& Lewis B.A. 1991. Methods for dietary fiber, neutral detergent fiber, and nonstarch polysaccharides in relation to animal nutrition. J. Dairy Sci. 74(10):3583-3597. <https://dx.doi.org/10.3168/ jds.S0022-0302(91)78551-2> <PMid:1660498>

Vedovatto M., Moriel P., Cooke R.F., Costa D.S., Faria F.J.C., Cortada Neto I.M., Pereira C.S., Bento A.L.L., Almeida R.G., Santos A.S. \& Franco G.L. 2019a. Effects of a single trace mineral injection on body parameters, ovarian structures, pregnancy rate and components of the innate immune system of grazing Nellore cows synchronized to a fixed-time AI protocol. Livest. Sci. 225:123-128. <https://dx.doi.org/10.1016/j.livsci.2019.05.011>

Vedovatto M., Moriel P., Cooke R.F., Costa D.S., Faria F.J.C., Cortada Neto I.M., Bento A.L.L., Rocha R.F.A.T., Ferreira L.C.L., Almeida R.G., Santos A.S. \& Franco G.L. 2019b. Effects of a single trace mineral injection at beginning of fixed-time AI treatment regimen on reproductive function and antioxidant response of grazing Nellore cows. Anim. Reprod. Sci. 211:106234.<https:// dx.doi.org/10.1016/j.anireprosci.2019.106234>

Vedovatto M., Pereira C.S., Cortada Neto I.M., Moriel P., Morais M.G. \& Franco G.L. 2019c. Effect of a trace mineral injection at weaning on growth, antioxidant enzymes activity, and immune system in Nellore calves. Trop. Anim. Health Prod. 52(2):881-886. <https://dx.doi.org/10.1007/s11250019-02056-0><PMid:31471881> 